\title{
PYELITIS OF INFANCY
}

\author{
I. MODE OF INFECTION * \\ RICHARD M. SMITH, M.D. \\ BOSTON
}

There have been two antagonistic theories advanced to explain the mode of the infection of the kidney in pyelitis of infancy. One theory maintains that the infection of the kidney takes place by the ascending route, through urethra, bladder and ureters; the other, that the infection comes by means of the blood and lymphatics. Before discussing the relative merits of these two theories certain facts in regard to pyelitis as it occurs in infants need to be noted. The disease is much more common in girl than in boy infants, the proportion being nearly three to one. The organism most frequently causing the disease is the colon bacillus, which is the offender in from 50 to 90 per cent. of cases. The pathology of the condition is well established. In uncomplicated cases the pelvis of the kidney is the only portion of the urinary tract involved, and there the local lesion is simply a low grade inflammation. The ureters and bladder are normal. Many cases show in addition some degenerative changes in the kidney substance, due to extension of the process inward from the pelvis. When the tissues are invaded by pus-forming cocci, there is secondary abscess formation.

With these facts as a basis, those who believe in the ascending route of infection argue that the colon bacillus enters the urethra, ascends against the urinary stream and, causing no lesions in its progress, localizes in the pelvis of the kidney and by its growth there gives rise to disease. This theory gains its greatest support from the large proportion of cases among girls, who, theoretically with a short urethra and of easy contamination with fecal matter, become more readily infected. There is very little experimental work in its support. Bond ${ }^{1}$ showed that in the intestine, fallopian tubes and biliary passages solid particles may be carried upward by a current hugging close to the surface, and that in the ureter, when no urine is coming down, this

* Submitted for publication May 18, 1916.

* From the Children's Medical Department, Massachusetts General Hospital.

* Read at the Twenty-Eighth Annual Meeting of the American Pediatric Society, held at Washington, D. C., May 8-10, 1916.

1. Bond: Med. Rec., New York, 1905, 1xviii, 246. 
passage upward may also occur. Many others ${ }^{2}$ state the opinion that ascending infection may occur in some or all cases, but they have no sure evidence to support the belief.

Directly against the ascending method of infection are the facts that colon bacilli have never been shown to pass up the normal, unobstructed ureter and that the colon and tubercle bacilli have been introduced repeatedly into the bladder and in the presence of a normal mucous membrane are excreted without causing damage of any kind. ${ }^{3}$ Ascending infection occurs only in the presence of obstruction to the outflow of urine and cannot occur if the sphincter of the ureter is normal. ${ }^{4}$ It seems to me that the ascending theory of kidney infection so far as it applies to the pyelitis of infancy has not been proved and the facts are against it.

The theory of kidney infection by the blood and lymphatics rests upon much surer ground. The work of Thiele and Embleton ${ }^{5}$ seems to show that bacteria may pass to the kidney by the lymphatics alone, appearing first in the fat capsule and being distributed through the kidney also by the lymphatics. If bacteria appear in the urine, that is, if they have passed through the kidney, they must have reached the kidney by the blood stream. This latter procedure is what occurs in pyelitis, so we must have had a blood infection.

The direct lymphatic connection as shown by Franke ${ }^{6}$ between the colon and the right kidney, which is the kidney most frequently affected in unilateral infection, has led some writers ${ }^{7}$ to believe that bacteria pass directly from the intestine to the kidney by these lymph

2. Among these may be cited the following:

Thomas, J.: Lancet, London, 1913, ii, 467.

Wright: Practitioner, London, 1909, 1xxxii, 344.

McCrea: Practitioner, 1910, 1xxxv, 346.

Wyman: Boston Med. and Surg. Jour., 1914, clxx, 540.

Freeman: Jour. Am. Med. Assn., 1914, 1xiii, 1802.

Cunningham: Jour. Am. Med. Assn., 1915, lxiv, 231.

Heubner: Jahrb. f. Kinderh., 1913, lxxvii, 1.

Ross: Lancet, London, 1915, i, 654.

Shaw: Clin. Jour., 1908, xxxi, 273.

Box: Brit. Med. Jour., 1910, ii, 1128.

Barnard: Lancet, London, 1905, ii, 1243.

Herringham: Clin. Jour., 1909-1910, xxxv, 241.

Sampson: Bull. Johns Hopkins Hosp., 1903, xiv, 334.

3. Leutscher: Bull. Johns Hopkins Hosp., 1911, xxii, 361. Bauereisen: Ztschr. f. gynäk. Urol., 1910, ii, 132.

4. Rovsing: Sixteenth International Medical Congress, Budapest, 1909.

5. Thiele and Embleton: Proc. Roy. Soc. Med., Path. Sec., 1913-1914, vii, 69.

6. Franke: Mitt. a. d. grenzgeb. d. Med. u. Chir., 1911, xxii, 623; Ibid., 1911, xlviii, 1973.

7. Wilson: Brit. Jour. Child. Dis., 1913, x, 289. Jeffrey: Quart. Jour. Med., 1910-1911, iv, 267. 
vessels-the so-called transparietal route. This probably occurs, but gives rise to an infected kidney, not to pyelitis as we see it in infants. Pyelitis may follow this condition by secondary blood infection.

The usual mode of infection in pyelitis appears to be somewhat as follows: From the intestinal tract or some other source bacteria get into the lymphatic vessels and then into the blood, or possibly directly into the blood. They are transferred by the blood to the kidney. After reaching the kidney they pass through the glomeruli and are excreted at the pelvis. They may pass out of the body in the urine without doing any damage, or they may set up an infection at their point of excretion, that is, produce a pyelitis. They may during their passage through the kidney cause more or less damage to the various portions of the organ. Which of the alternatives occurs within the kidney depends on the virulence and character of the bacteria and on the resistance of the individual and of the local tissues. The colon bacillus, being of comparatively low pathogenicity, causes almost no damage to the kidney substance in its passage through the organ. An infection of the kidney may take place by extension inward from the pelvis, probably by lymphatic channels. This infection causes a greater or less degree of permanent damage to the substance of the kidney and presents a complication of, or sequel to, the usual pathology of the disease. The various stages in this process as outlined in the foregoing statement have been well established.

Blood infection in nearly all the acute infectious diseases is now so well known that no proof needs to be given in its support. The colon bacillus has been found in the blood by several investigators. ${ }^{8} \mathrm{Crab}-$ tree found that organism in the blood in seven out of nine patients who developed pyelitis under observation. The blood infection was always early in the disease, disappearing later, as in typhoid fever.

The intestinal tract is the most likely source of the infection in the majority of cases of pyelitis, especially in those due to the colon bacillus. Calmette ${ }^{0}$ and many others ${ }^{10}$ have shown that pigment par-

8. Crabtree: Lancet-Clinic, 1916, cxv, 96. Moser: Deutsch. Ztschr. f. Chir., 1915, cxxxii, 71. Ruediger: Philippine Jour. Sc., 1915, x, 25.

9. Calmette: Ann. de l'Inst. Pasteur, 1905, xix, 601; Ibid,, 1906, xx, 353. 609 ; Compt. rend Soc. de biol., 1906, 1xi, 161, 548.

10. Among these may be cited the following:

Arbeiter: Virchows Arch. f. path. Anat., 1910, cc, 321.

Whitla and Symmers: Brit. Med. Jour., 1908, ii, 61.

Nichols: Jour. Med. Research, 1904, xii, 455.

Ford: Tr. Assn. Am. Phys., 1900, xv, 389.

Adami : Montreal Med. Jour., 1898, xxvii, 485; 1902, xxxi, 105.

Cobbett: Jour. Path. and Bacteriol., 1910, xiv, 563.

Griffith: Royal Commission on Tuberculosis, Second International Report, 1907, Appendix 1, 628, 696.

Ravenel: Jour. Med. Research, 1903, x, 460.

Ravenel and Reichel: Jour. Med. Research, 1908, xviii. 1. 
ticles, tubercle bacilli and other bacteria are carried with the fat from the intestinal canal in the lymph vessels of the mesentery during digestion and are distributed by the blood to all parts of the body, including the kidney. Other writers have called attention to the passage of the colon bacillus through the damaged intestinal mucous membrane, ${ }^{11}$ and to the frequent association of pyelitis with constipation and other digestive disturbances. ${ }^{12}$ Ten Broeck ${ }^{13}$ found organisms of the colon bacillus group post mortem in the heart's blood of five out of fourteen patients dying of infectious diarrhea and in the ileocecal lymph nodes in five cases. Trumpp ${ }^{i 4}$ found colon bacilli in the urine of fourteen out of seventeen children with follicular enteritis. Morse ${ }^{15}$ and Knox ${ }^{16}$ include cases of pyelitis in their reports of urinary analyses in gastrointestinal diseases. Kowit $z^{17}$ has emphasized the seasonal incidence of pyelitis following the diarrheas of summer. Edith Williams ${ }^{18}$ found in urine cultures of seventy consecutive cases that of forty-four patients with chronic intestinal disorders, sixteen showed colon bacilli. The importance of considering the gastro-intestinal tract in the treatmen of pyelitis has been emphasized by many writers ${ }^{10}$ and is well known to all who have had experience with the disease. MacGowan ${ }^{20}$ says he has seen a direct rise and fall of the bacilli in the urine with the neglect or care of the bowels.

Undoubtedly, there are sources of infection other than the gastrointestinal tract, such as the teeth, tonsils and local septic lesions. Several writers ${ }^{21}$ have emphasized this and the necessity of finding and

11. Park: Tr. Am. Surg. Assn., 1893, xi, 213. French: Brit. Med. Jour., 1908, i, 1029. Thiemich: Jahrb. f. Kinderh., 1910, 1xxii, 243.

12. Brennemann: Jour. Am. Med. Assn., 1911, 1xi, 631. Friedenwald: Arch. Pediat., 1910, xxvii, 801. Dudgeon: Lancet, London, 1908, i, 615. Green: Boston Med. and Surg. Jour., 1913, clxviii, 645. Cannato and Caronia: Pediatria, 1914, xxii, No. 9. Langstein: Med. Klin., 1913, ix, 1491. Zobel: Jour. Am. Med. Assn., 1916, 1xvi, 496. White, W. H.: Lancet, London, 1912, ii, 1204.

13. Ten Broeck: Boston Med. and Surg. Jour., 1915, clxxiii, 284.

14. Trumpp: Jahrb. f. Kinderh., 1897, xliv, 268.

15. Morse and Crothers: Arch. Pediat., 1909, xxvi, 561.

16. Knox and Meakins: Arch. Int. Med., 1908, ii, 241.

17. Kowitz: München. med. Wchnschr., 1914, 1xi, 1341.

18. Williams, E.: Lancet, London, 1912, ii, 511.

19. Among these may be cited the following:

Pardoe: Brit. Med. Jour., 1910, ii, 1129.

Briscoe: Lancet, London, 1909, ii, 1269.

Hutchinson: Clin. Jour., 1911, xxxviii, 209.

Thompson, W. H.: Med. Rec., New York, 1910, 1vii, 907.

Pringle: Practitioner, London, 1911, 1xxxvii, 35.

Jeff reys: Quart. Jour. Med., 1911, iv, 267.

20. MacGowan: Jour. Am. Med. Assn., 1915, 1xiv, 226.

21. Rawles: Med. Rec., New York, 1911, 1xxx, 707; Ibid., 1912, 1xxxi, 359. Smith, F. H.: Old Dominion Jour. Med. and Surg., 1914, xix, 77. Nice: South. Med. Jour.. 1915, viii, 1027. Grulee and Gaarde: Jour. Am. Med. Assn., 1915, Ixv, 312. Huet: Nederl. Tijdschr, v. Geneesk., 1916, p. 521, abstr. Jour. Am. Med. Assn., 1916, 1xvi, 993. 
removing the source of infection. The extra-intestinal sources are especially important in those cases in which the organism is some other than the colon bacillus. A patient of mine well illustrates this point: An infart 2 days old had a high temperature, a few impetiginous pustules on the neck and a pyelitis. The organism in the pustules was Staphylococcus aureus and the same organism was in the urine. After the healing of the skin lesions the pyelitis quickly disappeared.

The work of $\mathrm{Kraus}^{22}$ has shown definitely that bacteria may pass through the kidney without causing lesions in its substance. If staphyiococci are injected into the ear of a rabbit, they cause lesions in the heart, abdominal wall and pyramids of the kidney passing through the glomeruli without setting up inflammation. Honeij ${ }^{23}$ found leprosy bacilli in the urine of patients during the febrile stage of the disease. Brown, ${ }^{24}$ Rist and Kindberg ${ }^{25}$ and Foulerton and Hillier ${ }^{26}$ found tubercle bacilli in the urine of patients whose kidneys were not damaged. Crabtree has injected the paratyphoid organism into the rabbit and recovered it from the urine. At necropsy the kidneys were normal.

The infection of the pelvis of the kidney from within, that is, by bacteria brought to it by the blood and excreted, seems established.

The possibility of the infection of the kidney substance from infection in the pelvis was shown by Kumita, ${ }^{2 i}$ who demonstrated the extensive lymphatic connection between all parts of the kidney. That such infection actually occurs has been demonstrated by Hugh Cabot and $\mathrm{Crabtree}^{28}$ and supported by A. Müller. ${ }^{2 \theta}$

This statement of the mode of infection in pyelitis satisfies all the conditions except in offering an explanation for the greater frequency of the disease in females. This explanation is not hard to find, for no mention has been made of a very important source of lymphatic and blood infection of the kidney, namely, the pelvic organs. Poirier ${ }^{30}$ and Sobotta $^{31}$ have shown that the lymphatic vessels draining the pelvic organs are connected by free anastomosis with the kidney. These vessels drain through the thoracic duct into the blood. Sweet and Stewart ${ }^{32}$ proved experimentally that when the ureters were cut and sewed into the intestinal canal, if infection of the kidneys occurred,

22. Kraus: Arch. f. exper. Path. u. Pharmakol,, 1896, xxxvii, 1.

23. Honeij: Jour. Infect. Dis., 1915, xvii, 376.

24. Brown, L.: Jour. Am. Med. Assn., 1915, 1xiv, 886.

25. Rist and Kindberg: Presse med., 1914, xxii, 177.

26. Foulerton and Hillier: Brit. Med. Jour., 1901, i, 774.

27. Kumita: Arch. f. Anat. u. Path.. Anat. Abt., 1900, xlix, 94.

28. Cabot, H., and Crabtree: Unpublished communication.

29. Müller: Ztschr. f. Urol., 1912, Supplement.

30. Poirier: The Lymphatics, Constable, London, 1903, Translation by Leof.

31. Sobotta: Human Anatomy, 1907.

32. Sweet and Stewart: Surg., Gynec. and Obstet., 1914, xviii, 460. Stewart:

Univ. Penn. Med. Bull., 1910, xxiii, 233. 
TABle 1.-Detailed Record of the Cultures Made from the Secretions of the Vagina in Girls.of Various Ages

\begin{tabular}{|c|c|c|c|c|c|c|c|c|}
\hline Case & & Age & $\begin{array}{c}\text { No } \\
\text { Growth }\end{array}$ & $\begin{array}{l}\text { Staph- } \\
\text { ylococci }\end{array}$ & $\begin{array}{c}\text { Strepto- } \\
\text { cocci }\end{array}$ & $\begin{array}{c}\text { Gram. } \\
\text { Negative } \\
\text { Bacilli }\end{array}$ & Colon & $\begin{array}{l}\text { Other } \\
\text { Organisms }\end{array}$ \\
\hline \multirow[t]{2}{*}{1} & 2 & hours......... & + & & & & & \\
\hline & 30 & hours......... & .. & + & . & + & & \\
\hline \multirow[t]{2}{*}{2} & 6 & hours......... & + & & & & & \\
\hline & 34 & hours......... & .. & + & & & & \\
\hline \multirow[t]{3}{*}{$3^{*}$} & 6 & hours.......... & .. & . & + & & & \\
\hline & 6 & hours......... & .. & . & + & & & \\
\hline & 13 & days........... & .. & + & + & + & & \\
\hline 4 & 22 & hours......... & .. & .. & + & & & \\
\hline \multirow[t]{2}{*}{$\mathbf{5}$} & 7 & hours.......... & + & & & 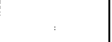 & & \\
\hline & 8 & days............. & .. & + & + & & & \\
\hline \multirow[t]{2}{*}{6} & 2 & days.......... & .. & + & & & & \\
\hline & 11 & days........... & .. & + & + & + & & \\
\hline 7 & 3 & days........... & .. & + & . & .. & .. & $\begin{array}{l}\text { Spore bearing } \\
\text { gram. neg. bac. }\end{array}$ \\
\hline \multirow[t]{2}{*}{8} & 4 & days...... & .. & + &. & + & & \\
\hline & 9 & days... & .. & + & .. & + & & \\
\hline \multirow[t]{4}{*}{$\theta$} & 21 & hours.. & + & & & & & \\
\hline & 2 & 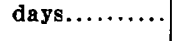 & .. & + & .. & + & & \\
\hline & 5 & days.......... & . & + & & & & \\
\hline & 8 & days............. & .. & .. & + & & & \\
\hline \multirow[t]{3}{*}{10} & 7 & hours.......... & + & & & & & \\
\hline & 3 & days........... & .. & + & + & .. & .. & $\underset{\text { bac. }}{\text { Gram positive }}$ \\
\hline & 6 & days... & $\cdot \cdot$ & + & & & & \\
\hline 11 & 8 & 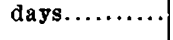 & .. & + & & & & \\
\hline \multirow[t]{3}{*}{12} & 2 & days............. &.$\cdot$ & + & & & & \\
\hline & 5 & days............. & .. & + & .. & + & & \\
\hline & 8 & 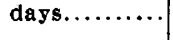 & .. & + & .. & *. & + & \\
\hline \multirow[t]{2}{*}{13} & 18 & hours......... & .. & + & + & & & \\
\hline & 4 & days............ & .. & + & + & & & \\
\hline \multirow[t]{2}{*}{14} & 7 & hours.... & + & & & & & \\
\hline & 3 & days........... & 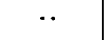 & .. & + & & & \\
\hline \multirow[t]{2}{*}{15} & 2 & days............... & .. & + & .. & + & & \\
\hline & 5 & 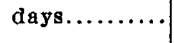 & .. & + & & & & \\
\hline 16 & 24 & hours.... & + & & & & & \\
\hline \multirow[t]{4}{*}{17} & 3 & years.......... & . & .. & + & & & r. \\
\hline & 3 & years..... & .. & .. & + & & & \\
\hline & 3 & years........... & $\because$ & .. & + & & & \\
\hline & 3 & years........... & .. & .. & .. & + & & \\
\hline
\end{tabular}

* Secretion taken from the vulva. + Secretion taken from the urethra. 
TABle 1.-Detalled Record of the Cultures Made from the Secretions of the Vagina IN Girls of Various Ages-(Continued)

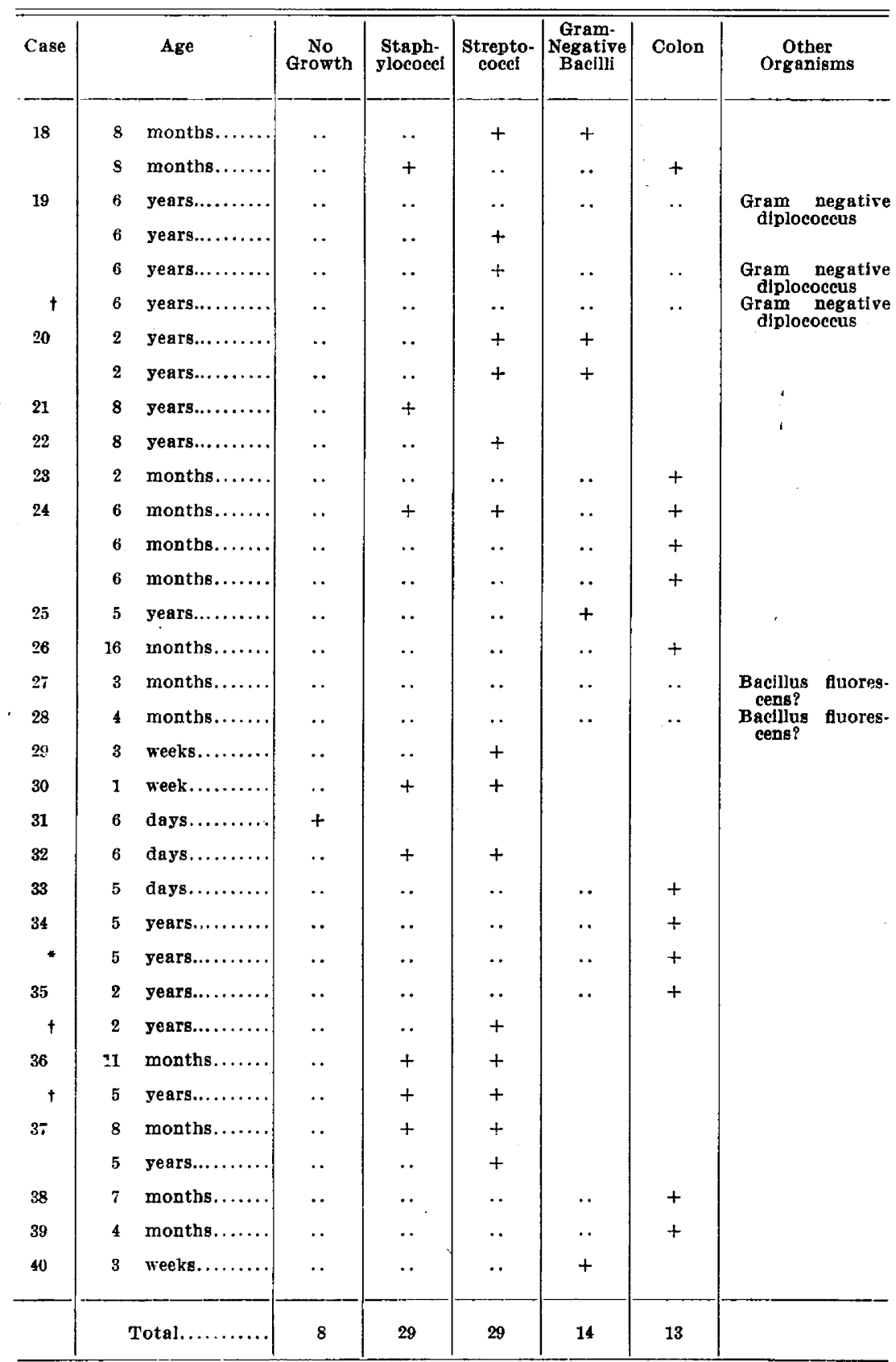

* Secretion taken from the vulva. + Secretion taken from the urethra. 
it was through the lymphatics about the ureters not through the lumen of the ureter. Sakata, ${ }^{33}$ Sugimura, ${ }^{34}$ Bauereisen, ${ }^{3}$ J. Thomson, ${ }^{35}$ W. B. Clarke, ${ }^{36}$ and Eisendrath and Kahn, ${ }^{37}$ working on the problem of kidney infection, all come to the same conclusion, that the lymphatics, not the ureters, play the major rôle in conveying direct infection from the pelvic organs to the kidney. If bacteria get into the lymphatics, they may get into the blood through the thoracic duct and thus to the kidney, or possibly into the blood from the infection in the kidney, and cause a pyelitis. Thiele found bacteria in the blood and urine from pelvic infection. Cases of pyelitis following circumcision have been reported by many writers. Rovsing ${ }^{38}$ in 1897 reported several cases of pyelitis in young married women, following rupture of the hymen. The female genital organs, with the close proximity of the urethra, vulva and vagina to the rectum and the semi-closed character of the parts, offer every advantage for the entrance and growth of colon bacilli and other bacteria.

To see whether this region was in fact a possible source of infection, I have made seventy-one cultures from the vagina, vulva or urethra of forty infants and young children. One infant 6 hours old and all over 18 hours old, except one infant 6 days old, showed a growth from vaginal culture. All the vulval and urethral cultures were positive. The first organisms to appear were streptococci and staphylococci and then small bacilli-not colon. Colon bacilli were found in vaginal cultures of infants as early as the fifth day.

The colon bacillus was identified by the following characteristics: motile bacillus, gram negative, obtained from characteristic (shiny, dirty, brown, confluent) colony on agar, giving acid coagulation of litmus milk, forming gas in glicose, and producing characteristic (as above) growth on potato.

The other bacillus frequently found was delicate, nonmotile, gram negative, causing no change in litmus milk, forming no gas in glucose and easily outgrown even by streptococci.

These findings are in accord with Schmidgall, ${ }^{39}$ who found the vagina of newborns sterile ten out of thirteen times, and by the second day a profuse growth of cocci. The colon bacillus was isolated twelve times out of twenty-one in newborns after the second day. She

33. Sakata: Arch. f. Anat. u. Physiol., Anat. Abt., 1903, 1.

34. Sugimura: Virchows Arch. f. path. Anat., 1911, xx, 206.

35. Thomson, J.: Quart. Jour. Med., 1909-1910, iii, 251.

36. Clarke, W. B.: Clin. Jour., 1911, xxxviii, 177. Walker: Lancet, London, $1913, \mathrm{i}, 435$.

37. Eisendrath and Kahn: Jour. Am. Med. Assn., 1916, 1xvi, 561.

38. Rovsing: Ann. d. mal. d. org. génito-urin., 1897, xv, 897, 1009, 1121, 1251 ; Ibid., 1898, xvi, 179, 278.

39. Schmidgall: Beitr. z. Geburtsh u. Gynäk., 1914, xix, 190. 
showed also that the vaginal secretions did not kill off the pathogenic organisms. Others ${ }^{40}$ have found bacilli and cocci in the vagina and vulva of infants in differing proportions. Alsberg in adults found the colon bacillus in 100 per cent. of cases in the urethra of women and concludes that it is a regular habitant of the female urethra.

A possible source of infection with colon bacilli or other bacteria is certainly present in the female vulva, urethra and vagina, and a slight trauma might easily accomplish the entrance of organisms into the lymphatic vessels and blood and thus permit their transportation to the kidney.

I think that we have sufficient evidence to believe that pyelitis is always a blood infection and that the bacteria frequently gain entrance to the blood by the lymphatics. In the uncomplicated cases the lesion remains localized in the pelvis of the kidney, where the organisms are excreted. Secondary infection of the kidney substance may occur by lymphatic channels from the pelvis. Quite possibly these secondary infections account for many "relapses." The source of the infection in the majority of cases, considering males and females together, is the gastro-intestinal tract. Some cases may arise from infection in the skin, teeth or tonsils or in some local septic process. Many cases in females, accounting for the greater number in this sex as compared with the males, arise from bacteria entering the blood, often via the lymphatics, from the urethra, vulva or vagina,

I wish to express my thanks to Dr. Franklin S. Newell for his kindness in permitting me to make cultures from infants at the Boston Lying-In Hospital, and to Dr. Richard S. Eustis and Dr. John W. Hammond, Jr., for assistance in the laboratory.

329 Beacon Street.

40. Among these may be cited the following:

Menge: Deutsch. med. Wchnschr,, 1894, xx, 867.

Strognoff: Monatschr. f. Geburtsh u. Gynäk., 1895, ii, 365.

Vahle: Ztschr. f. Geburtsh u. Gynäk., 1895, xxxii, 368.

Knapp: Monatsch. f. Geburtsh u. Gynäk., 1897, v, 84.

Neujean: Beitr. z. Geburtsh u. Gynäk., 1906, x, 408.

41. Alsberg: Arch. f. Gynäk., 1910, xc, 255. 